\title{
PLACE NAMES AS INGREDIENTS OF SPACE-RELATED IDENTITY
}

\author{
PETER JORDAN \\ Austrian Academy of Sciences
}

\section{ABSTRACT}

The article ${ }^{1}$ highlights the role of place names in space-related identity building from a cultural-geographical perspective. Starting from the various relations between the culture of a social group and geographical space in general (culture makes use of natural resources; culture reflects itself in space, shapes space creating a cultural landscape; a cultural group receives a part of its identity through the cultural landscape) the paper investigates in which of these relations place names play a major role. It is found that place names have important functions in all three relations: in making use of natural resources when they reflect natural characteristics, in cultural transformation of the geographical space when they shape it both visually and mentally as well as in identity building with individual members of a cultural group and with a cultural group in total when place names function as labels and support emotional ties between man and place.

[1] RELAtions betweEn the CULTURE OF A SOCIAL GROUP AND GEOGRAPHICAL SPACE

If culture is understood as a comprehensive concept ${ }^{2}$, as the complex of all human expressions, as all the specific ways in which human activities can be exerted, not only in the sense of elite culture (music, literature, fine arts), then, from a cultural-geographical perspective the relation between the culture of a social group and geographical space can in modification of Carl Sauer (Sauer 1925), (Sauer 1941) and George W. White (White 2004) be defined as threefold (see also Fig. 1). Culture of a specific group

- makes use of natural resources (offered by geographical space);

- reflects itself in space, shapes space creating a cultural landscape;

[1] This article is an amended version of Jordan (2009), published in Wiener Schriften zur Geographie und Kartographie, vol. 18 (see references). Also this version profits from English language editing kindly provided by Catherine Cheetham for the former version.

[2] For concepts of culture see a.o. Lévi-Strauss (1949), Kroeber \& Kluckhohn (1963), Lévi-Strauss (1966), Mitchell (2000). 
- receives identity through the cultural landscape.

It would seem beneficial to explain these three relations briefly in principle, before the role of place names within these relations is brought in.

\section{[1.1] Relation 1: Culture makes use of natural resources}

Natural resources of a certain place (vegetation, fauna, water, climate, morphology, soil, geology, location etc.) offer certain opportunities to inhabitants. Places rich in wood will very likely prompt the construction of wooden houses and also churches (Fig. 2 on page 120); barren and rocky places will rather lead to buildings made of stone. In lowlands clay is the construction material most easily available. And indeed, in most lowlands (Po Plain [Pianura Padana], Valachian Plain [Ţara Romaneasca], Great Hungarian Plain [Alföld], North German Plain [Norddeutsches Tiefland]) clay brick houses or adobe houses (air-dried clay bricks) are the traditional type. Places rich in fish will encourage inhabitants to develop a dining culture with fish playing a major role.

But it depends on the individual and on the social group, whether and to what extent the natural offer is accepted and in which (selective) way it is used. Nature offers opportunities and a certain choice, but does not really determine the result (Sauer 1941). Places similar in nature are likely to have broadly similar cultural landscapes and dining cultures rather close to each other, but they will rarely be completely the same.

It is, however, also true that in our globalising world, the natural offerings of a certain place are now far less limiting. Modern means of transportation and the networks of trade make it possible to transfer commodities easily from one place to another. In consequence, most modern housing or dining cultures have approached each other. It is nevertheless even nowadays hard to imagine that, e.g., the Finnish lifestyle will ever become exchangeable with the Italian (Mitchell 2000). Less developed parts of the world will anyway remain more dependent on local resources due to their economically restricted capacity to import goods. From empirical research it is evident that, e.g., nutrition in large parts of Africa has remained much closer to local natural resources than in the "developed Western World" (Liouty 1998, table 169).

[1.2] Relation 2: Culture reflects itself in space, shapes space creating a cultural landscape

Cultural elements (specifics of a certain culture) express themselves in the cultural landscape. The cultural element religion, e.g., manifests itself visibly by places of worship, in Christian countries usually by churches of varying architectonical style (Fig. 2), by chapels and field crosses as well as by cemeteries and places of pilgrimage. The architectonical type of a church very often allows a guess to which 


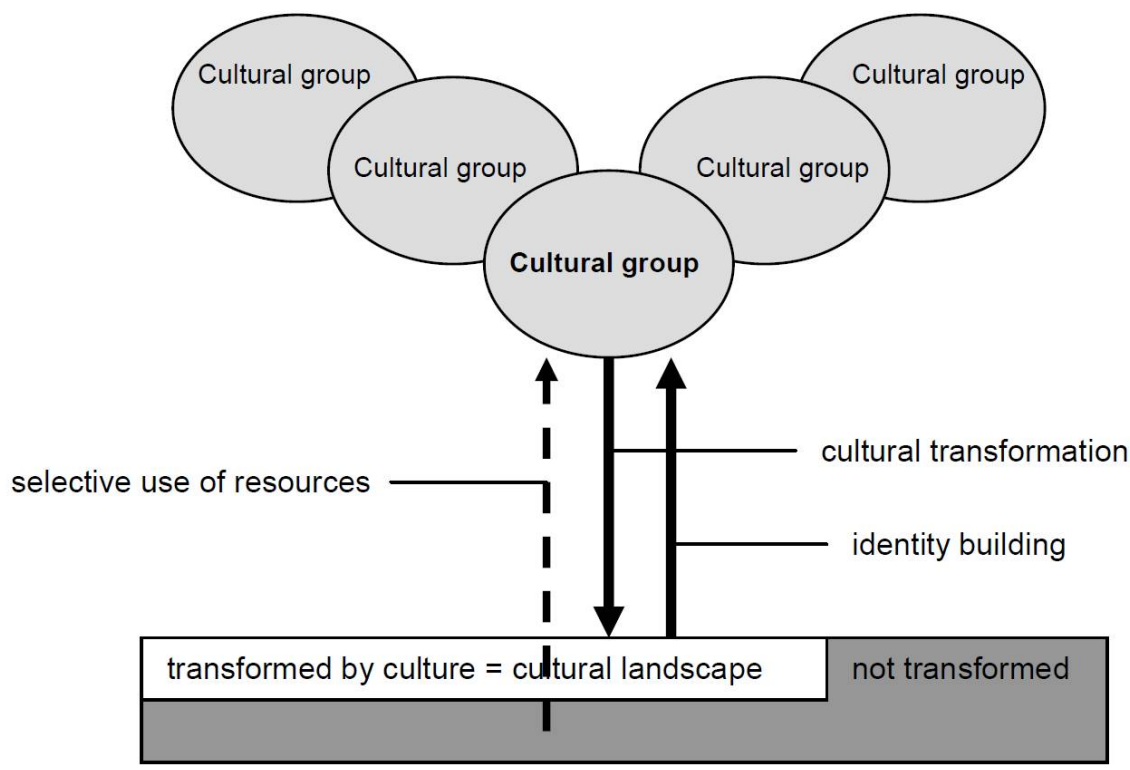

Geographical space

FIGURE 1: Relations between culture (of a group) and geographical space.

denomination it (and the population in its catchment) belongs. Language and script are visualised in the landscape by advertisements, shop names, sign posts, etc. The historiography of a certain culture is visibly reflected by monuments and museums. Architecture is, of course, a cultural element shaping geographical space most significantly and in various ways, which range from the popular architecture of farmsteads to rather elitarian architectonical manifestations as, e.g., representative buildings. The way a social group uses the land for agricultural and other economic purposes has also a strong impact on the character of a landscape: vineyards or olive groves are able to shape a landscape very specifically. But this is not much less true for foresting and pasturing, also for more recent types of land use like industry or road traffic.

Even the social stratification of a society including the question "who dominates?" can be answered by a look into the landscape. Societies with a dominance of large enterprises let cities with large office buildings and spectacular advertising emerge (Fig. 3), while the dominance of social aspects may result in largescale housing estates. Economic wealth is also sometimes very visibly reflected by beautiful suburban villa quarters, gated communities, etc. When religion has a strong position in society, the density of churches will be high, they will occupy prominent and symbolic places and perhaps outweigh other buildings also in size forming the most significant landmarks. 


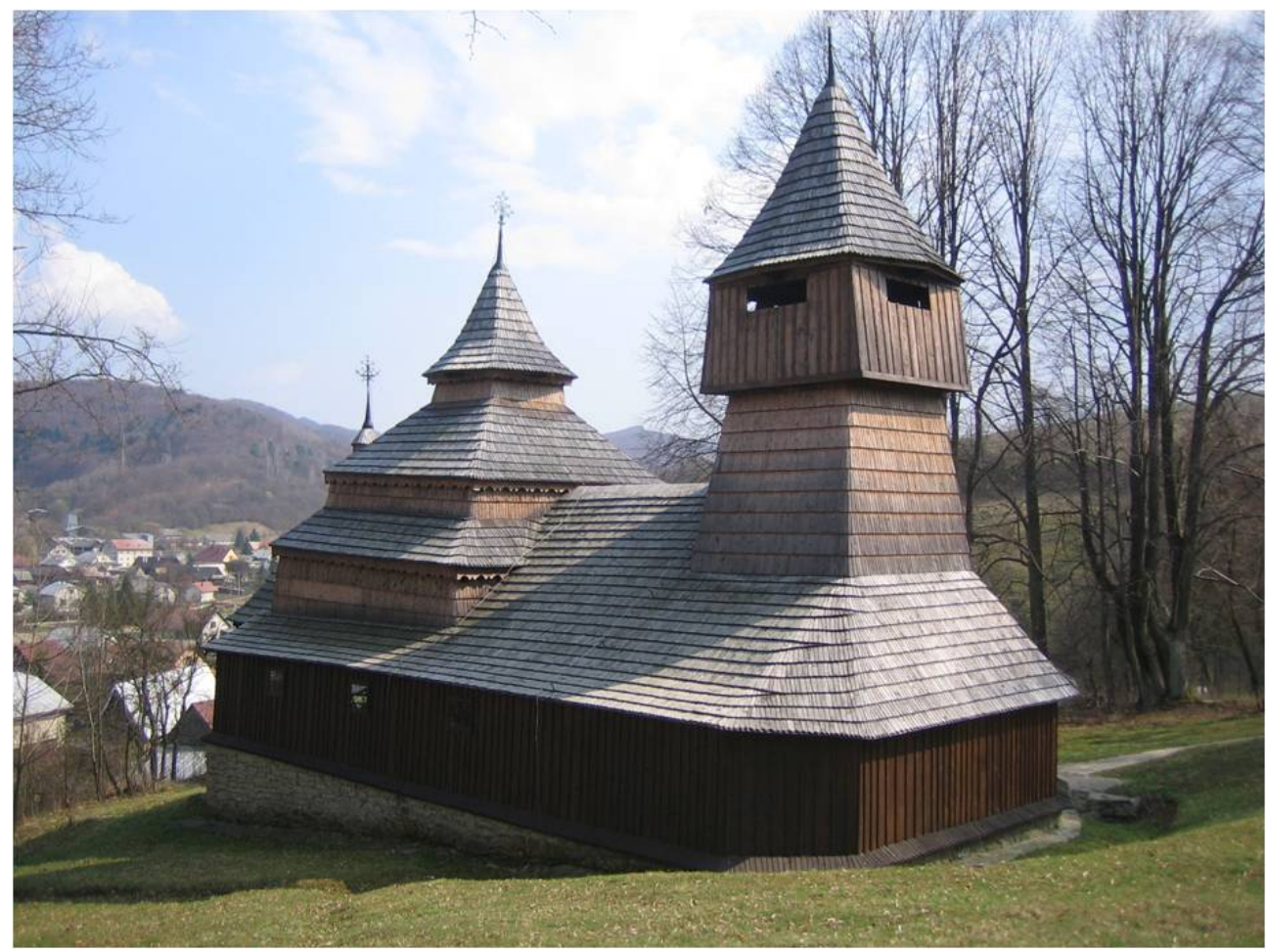

FIGURE 2: Wooden Greek-Catholic church in Lukov, Slovakian Carpathians (Photo April 2009).

In a way, each landscape tells a story about the culture by which it has been shaped. When the historical layers of a landscape are analysed, a temporal sequence of cultures can also be traced. The fact, e.g., that Vienna was for a long time the residence of an empire and that this has been its main urban function in a very formative period, can easily be deduced from the architectonical dominance of palaces over other buildings. Large social housing estates from the interwar period in turn may lead to the (very justified) conclusion that social aspects have dominated urban policy in this era.

Another striking example in this respect is Cluj-Napoca in Romanian Transylvania [Ardeal]. Although this city is today predominantly Romanian by nationality and Orthodox by denomination, the Catholic church of the Hungarians is located right in the centre of the city, at its main square, unmatched by any other landmark (Fig. 4). This reminds us of the fact that Roman-Catholic Hungarians have been the dominant societal force up to World War I and have remained remarkable in numbers even thereafter. 


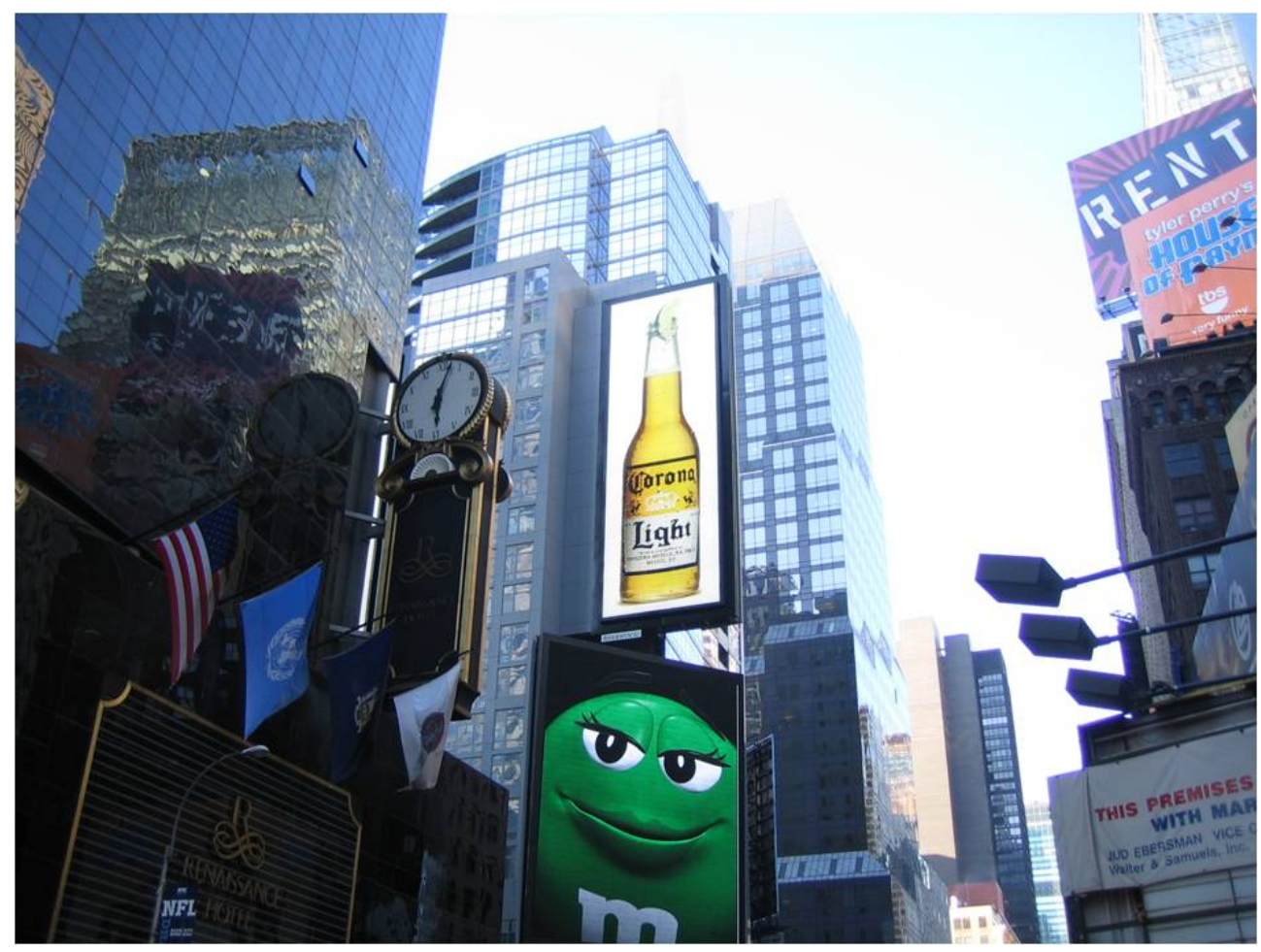

FIGURE 3: Skyscrapers and advertising near Times Square, New York (Photo April 2007). 


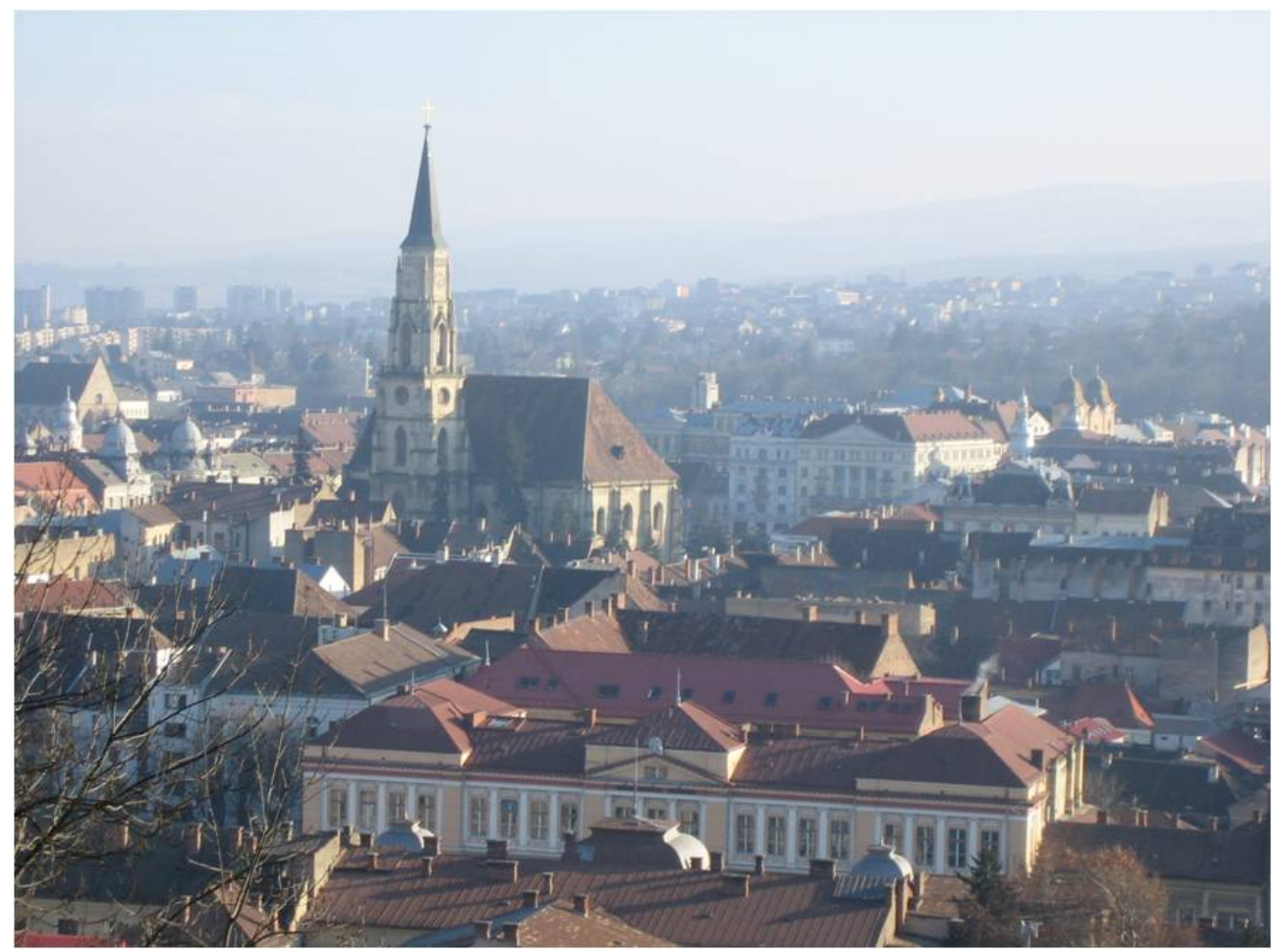

FIGURE 4: The Roman-Catholic church of the Hungarians dominates the face of downtown Cluj-Napoca, Romania (Photo January 2005). 


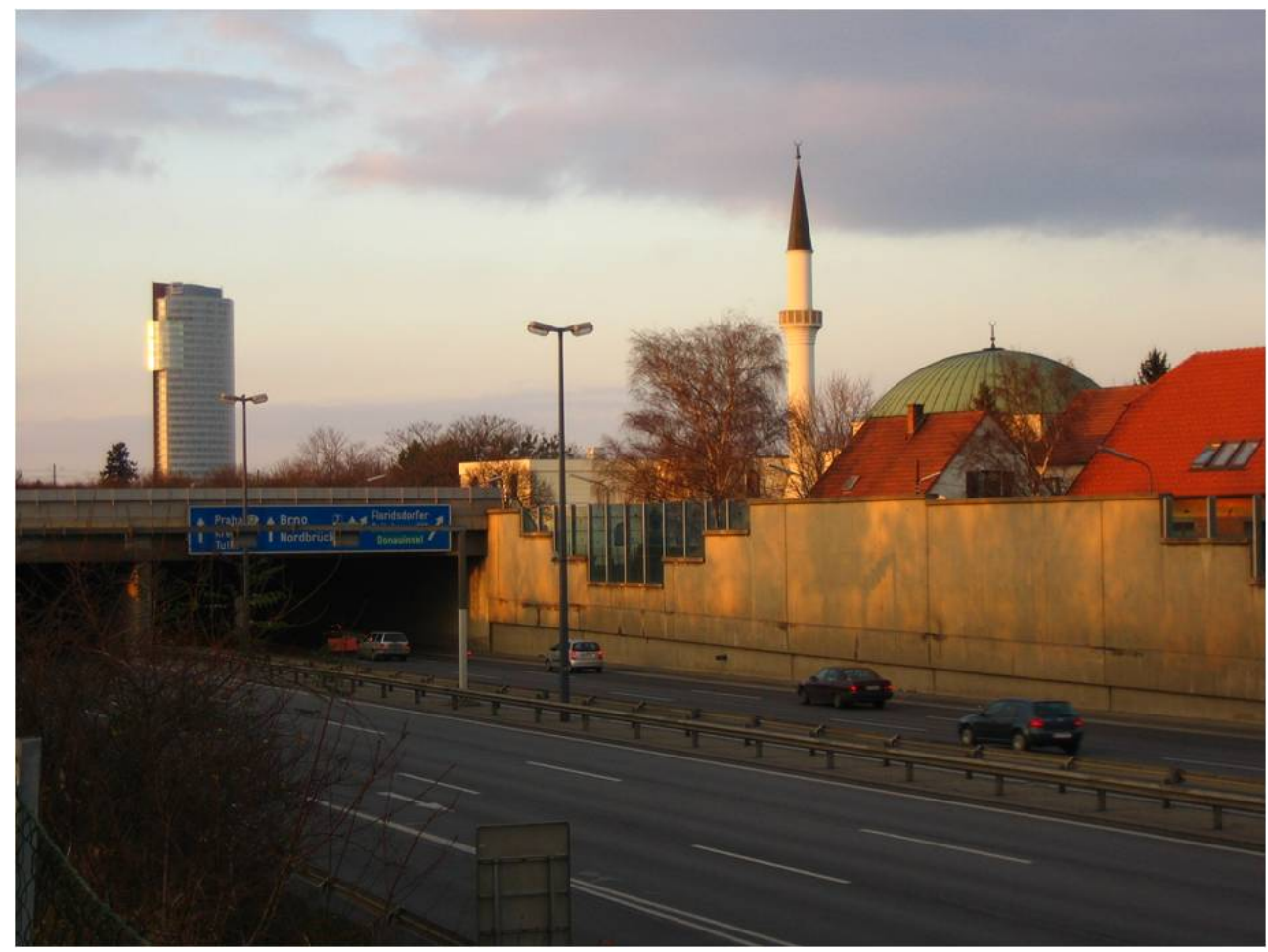

FIGURE 5: The only standard-type mosque in Vienna hidden away in the suburbs and behind a major road (Photo 2006)

But it also happens that social groups in a non-dominant or even clearly supressed position share a place with a dominant culture. In this case manifestations of their culture are not allowed to express themselves in the cultural landscape, have to be reduced in size or are banned to less prestigeous places. Up to the Charter of Religious Toleration by Jospeh II (1781), e.g., Protestants in Catholic Austria were not allowed to have churches. Also by the Charter they were only allowed to have churches without spire and bells and without a direct entrance from the street. Today, Vienna with its appr. 160,000 Muslims has certainly a lot of hidden places of Islamic worship, but just one standard-type mosque. This is located far from downtown at the less prestigeous left bank of the Danube behind a dam and a major road (Fig. 5).

[1.3] Relation 3: A cultural group receives a part of its identity through the cultural landscape

Personal as well as group identities are composed of various layers. 
The identity of every person is composed of multiple layers. Usual components are gender (male - female), education (primary, secondary, tertiary; direction), profession, social status, political and religious orientation. They may be ranked in various ways, and even other layers, not mentioned here, may dominate.

Group identity is in turn composed of language, religion and all the other cultural elements shaping a social group. Also here the ranking of the various aspects may vary. While, e.g., for Croats denomination is a more important characteristic of their group identity than language (their language is close to other South Slavonic languages like Serbian, Bosnian or Montenegrin), for Albanians it is the other way round, since the Albanian nation is split into several denominations (Muslim, Orthodox, Roman-Catholic), while it is distinct from other nations by its common and very specific language.

Personal as well as group identity are in addition shaped or at least supported by the cultural landscape. Having been born into a certain cultural landscape and having been socialised in it, a person becomes familiar with a specific type of architecture, scenery, land use, vegetation, climate (including typical weather situations), also with specific smells and sounds. He/she learns to interpret the processes, to read the symbols and codes of a cultural landscape. Most things happen as they are expected: the church bells ring at certain times of the day; it rains when dark clouds appear in the west; the smell of a pulp and paper factory will be in the air when southeasterly winds blow; cars start moving when traffic lights switch to green. This regularity conveys a good feeling, a feeling of security, predictability and safety. The cultural psychologist Ernest Emmerich Boesch expressed it in this way: "Home is where the living is easy" (Boesch 1983, 353).

Apart from this feeling of familiarity and safety the cultural landscape also conveys by this very reason culture. Having been shaped by the culture of a social group (in practice rather by some more active or respected individuals or by the driving and dominating forces of a group) it reflects this culture back to the group and - this time - to all its members. As regards this effect, it differs only in kind from the educational system or from grandmother's narrative, just to mention two other (rather divergent) conveyers of culture. The landscape, into which a person has been born and in which he/she has been socialised or to which he/she has become acquainted and familiar in his/her later life, is (including its symbolic code) usually unconsciously "read" and reminds the individual day by day of his/her cultural identity and conveys it from generation to generation.

Yi-Fu Tuan, a disciple of Carl Sauer, the founder of the Berkeley School of Cultural Geography, formulated it in this way:

„[Place] is made up of experiences, mostly fleeting and undramatic, repeated day after day and over the span of years. It is a unique blend of sights, sounds, and smells, a unique harmony of natural and artifi- 
cial rhythms such as times of sunset, of work and play. The feel of a place is registered in one's muscles and bones." (Tuan 1977, 183f)

Now let us bring place names in and try to find out which role they play within the three relations between culture and space mentioned.

\section{[2] THE ROLE OF PLACE NAMES WITHIN CULTURE-SPACE RELATIONS}

[2.1] Geographical names reflect spatial characteristics, most frequently natural characteristics, but also characteristics of settlement history, land use and economy, former feudal relations, historical events, etc. (Relation 1)

When place names reflect natural characterisitics, they refer mostly to location, exposition, morphology, waters, vegetation, soil conditions and mineral resources. They highlight in this way what was by a certain culture considered remarkable for a certain place and/or important under the aspect of human use and appropriation. Farming cultures use to have approaches different from, e.g., shepherders. While soil conditions are certainly important for farmers, shepherders may rather be focused on vegetation cover or morphology.

The Slavonic name Bistrica, for instance, which occurs not only in areas where currently Slavonic languages are spoken, but appears - mostly in derivations like, e.g., German Feistritz - also where a former Slavonic substratum has later been superimposed by other languages, characterizes a river or brook running quickly and has clear water. Javornik(y), in a German derivation also Jauernig, characterizes a specific of the vegetation (javor, 'maple').

The meaning of many names, however, is not transparent for people using these names today. Many belong to older layers of the own language or have their origin in other languages spoken earlier at the place.

This is true for most names of larger rivers. They have always been important features and were named very early. Later, their names were transferred from one language to another just by morphological and phonetic adaptation. A case in point is the name Danube, which can be traced back at least to Celtic, perhaps even to pre-Indo-European languages.

\section{[2.2] Place names contribute to shaping the cultural landscape (Relation 2)}

But place names shape geographical space also mentally by labelling spatial concepts (space-related ideas and images). In this way they support structuring geographical space, since name and concept are mostly closely linked. The name attributed to a concept cannot easily be exchanged against another one without modifying the concept. It would even be possible to state in general that place names identify places, if there was not the major exception of place names on maps: on maps a place is already sufficiently identified by the cartographic symbol positioned on the two-dimensional map face. The location of the cartographic 
symbol indicates undoubtedly a certain place. The place name has in this case only a clarifying, facilitating function - it makes identification easier, especially for map readers with a less precise mental map.

Structures in geographical space called regions are anyway results of mental processes. They exist, since the complex and vast variety of (really existing) features have been classified under certain (human) aspects. Would the aspects be others, different structures or regions would result from the classification. There is nothing like "natural" geographical regions. All divisions of space are in fact mental constructs, i.e. spatial concepts marked by names (see Weichhart et al. (2006)).

Many spatial concepts coincide with other imagined features like functional relations (e.g. administrative, economic) as in the cases of communes, provinces, states and other administrative units or in the cases of catchment areas of central places in the sense of Walter Christaller (Christaller 1933). Others correspond to natural features like to the land/sea divide (in the case of islands), to distinct morphological barriers (in the case of basins) or to clear climatic divides (in the case of climatic regions). But even when they seem to be shaped by nature (by the land/sea divide, morphological barriers, climatic divides), they do this only because nature is interpreted in a certain way, i.e. under the aspect of a resource for human activity.

But there are many spatial concepts lacking even such a coincidence. They are indeed pure projections of ideas onto a certain geographical space. This is especially true for the feature type of a cultural region in the sense of a region not (necessarily) defined by functional relations and administrative or natural boundaries, but by common history and cultural traditions. They may have been political units in the past and developed their common traditions during this time.

Two cases in point are the Croatian cultural region Dalmatia [Dalmacija] and the Austrian Salzkammergut. They functioned as administrative units in history (albeit with varying territorial reference, in the case of Salzkammergut even differing from the current concept), but are currently neither administrative nor functional, nor natural units. They have currently neither administrative boundaries nor a distinct centre, to which a catchment area gravitates in the socioeconomic sense. It would also be difficult to draw boundaries according to natural features around them. The names are in fact the only carriers of these spatial concepts. These concepts are nevertheless well associated with a specific imagination and rich in content. They are deeply and widely rooted in public consciousness, used by the local population, in scientific and popular literature as well as in the media and especially in tourism as brands. Hotels, restaurants, dishes, ships, newspapers a.o. are named after these regions, for these names have a favourable appeal. Nobody would say that these regions do not "exist". 
Not only in these rather specific cases, when names are actually the only carriers of spatial concepts and regional identities, but also in all other situations, when they just support identities carried also or mainly by other factors like boundaries, functional relations, land use (as it is with settlements), morphology (as it is with mountains, hills or plains) or the land/water divide (as it is with seas, lakes, rivers or islands) place names are most important for the definition of mental maps. The (more or less correct) mental map every one of us carries with $\mathrm{him} / \mathrm{her}$ is certainly also shaped by lines for boundaries, rivers, coasts, roads and railways, by dots and circles for settlements and by areal colours and patterns for altitudes, lakes and seas, but the essential links between these cartographic symbols and the spatial concepts and geographical features they mark are the names.

It is very true that this mental shaping of geographical space (not the least by place names) has no direct impact on the (visible) cultural landscape. But indirectly it has. If, e.g., a place is conceived as being a part of a certain cultural region, inhabitants may be inclined to construct their houses in the style typical for this cultural region.

\section{[2.3] Place name functions in space-related identity building (Relation 3)}

In space-related identity building place names have the function both of labels and of supporting emotional ties.

\section{Label function}

In the symbolic function of a label a place name represents a space-related concept filled with contents. The name conveys these contents to inhabitants of the place as well as to people from the outside insofar the latter know these contents or have learned about them (as this is, e.g., the case with tourism marketing). In this function place names are very similar to flags or coats of arms. It is characteristic for strong space-related identities that their names are reflected many times, e.g. in names of restaurants, hotels, dishes, ships, trains, newspapers etc.

How burdened with emotions the label function is can be derived from two facts: (1) administrations often refuse linguistic minorities the official use of their names and interpret this use as a territorial claim; (2) in multilingual areas official use of minority names frequently stirs up conflict among the local population. Naming is conceived as having the power of defining the identity of a place. A second name on the signpost is seen as conveying the impression that this place had a double identity and was not under the control of one group exclusively.

There are many conflicts arising from these grounds, even if only Austria and its closer neighbourhood are regarded.

In the Austrian province of Carinthia a law and a decree of 1976/77 ruled that 91 settlements had to have bilingual (German/Slovene) signposts (BGBl. Nr. 396/1976, BGBl. Nr. 306, 307, 308/1977), but only 70 signposts are so far installed 


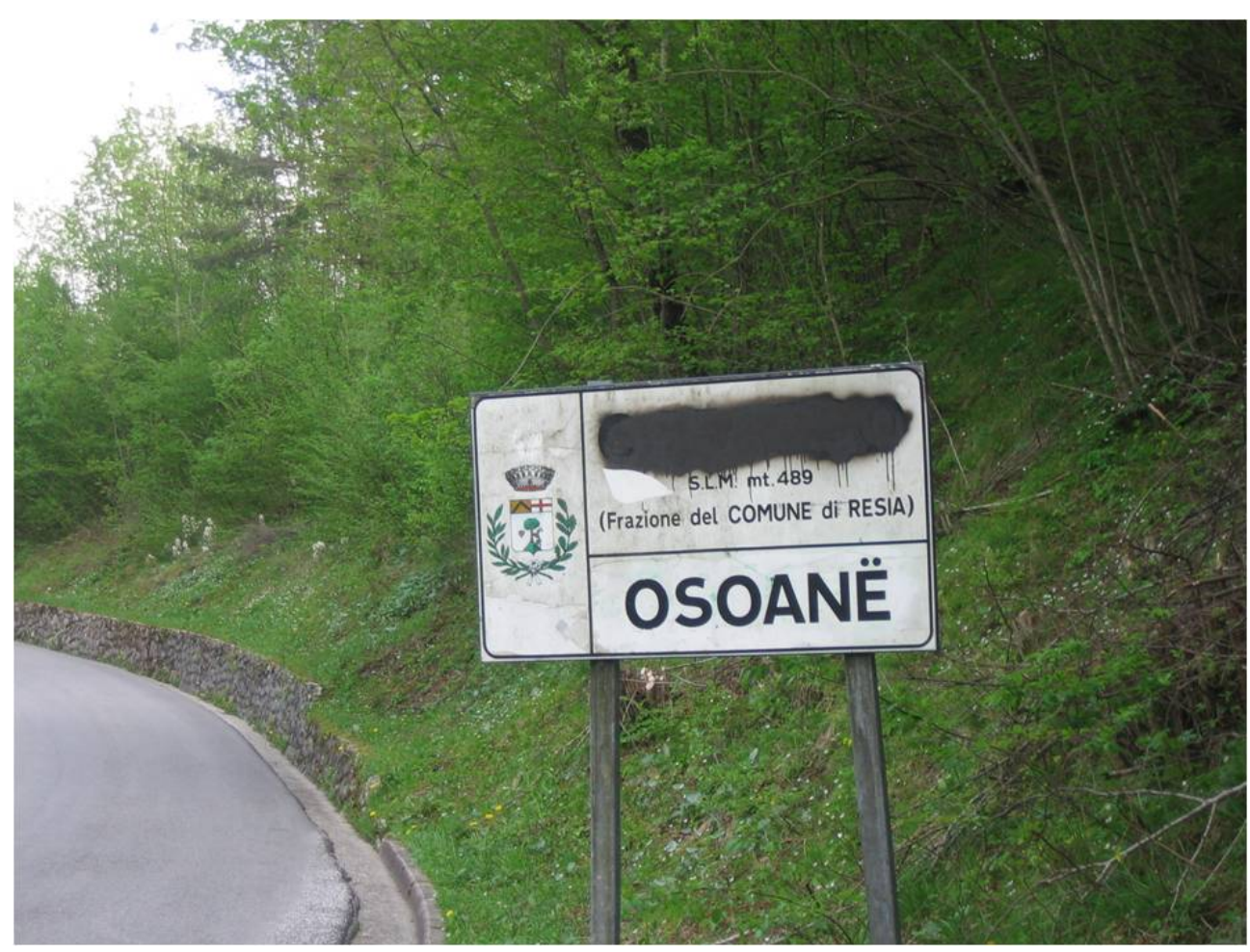

FIGURE 6: Damaged bilingual signpost in the Resia Valley. The Italian name Oseacco has been exstinguished, only the Resian name (with a letter $\ddot{e}$ not used in Slovene) has remained (Photo May 2008).

(see also Jordan 2006: 103ff). This is partly due to resistance of the majority population, partly also to the fact that the linguistic minority hesitates to declare itself. This again is mainly because the minority used to be the lower strata of society.

In the bilingual (Italian/Resian ${ }^{3}$ ) Resia Valley [Valle di Resia] of the autonomous Italian region Friuli-Venezia Giuglia many bilingual signposts have been damaged (Fig. 6).

In the Italian autonomous province of South Tyrol [Südtirol/Alto Adige] inhabited by a German-speaking majority which dominates politically and economically, a place names law has not yet been able to be passed because a large part of the German speaking group demands that Italian place names introduced after WWI are not to remain official. This attitude does not recognise that these place

[3] Local speakers classify a Slavonic idiom written in an alphabet differing from the Slovene as a language of its own and call it Resian while in Slovenia it is usually classified as a Slovene dialect (see e.g. Logar \& Rigler 2001). 
names have in the meantime acquired an important function in space-related identity building for the third, fourth and fifth generations of Italian immigrants.

Function of supporting emotional ties

The function of supporting emtional ties affects only persons well-acquainted with a certain place. These are in the first line inhabitants; secondly also people, who have been socialised in a certain place and later left it; thirdly also persons, who have only in a later stage of their life found a certain emotional relation to a place, e.g. as frequent vacationers.

For them mentioning or memorising a name means to strengthen "the feel of a place" as Yi-Fu Tuan puts it (Tuan 1977, 183f) and to let the emotional tie with it grow. In this function place names are an important factor of "feeling at home".

Both functions are especially important for linguistic minorities. While the identity of cultural majorities is usually (except in border regions) not challenged day by day, minorities are usually in a more defensive position and feel therefore a special need to demonstrate that they exist, have been present for generations, and have co-shaped the culture and cultural landscape of a certain place. Place names in their own language on signposts, on maps, in official documents are most likely more than for others important in their symbolic function as a label as well as in their function to support emotional affiliation. For the member of a minority, place names in his/her language in official use (e.g. on a signpost) very often symbolise recognition, a confirmation to be accepted by the majority and to be at home at this place. For this very reason it would be wise of administrations to admit minority names officially. For this very reason also, Romania goes as far as to represent Ukrainian and Russian place names in their original Cyrillic script on signposts and not to transliterate them (Fig. 7). They are to address in the first line the Ukrainian/Russian inhabitants and make them feel at home, and are not so much meant as information for external visitors.

\section{[3] CONCLUSION}

Place names have important functions in all three relations between cultural groups and geographical space: in making use of natural resources when they reflect natural characteristics, in cultural transformation of the geographical space by shaping it visually and mentally, in identity building with individual members of a cultural group and with a cultural group in total as labels and in supporting emotional ties. 


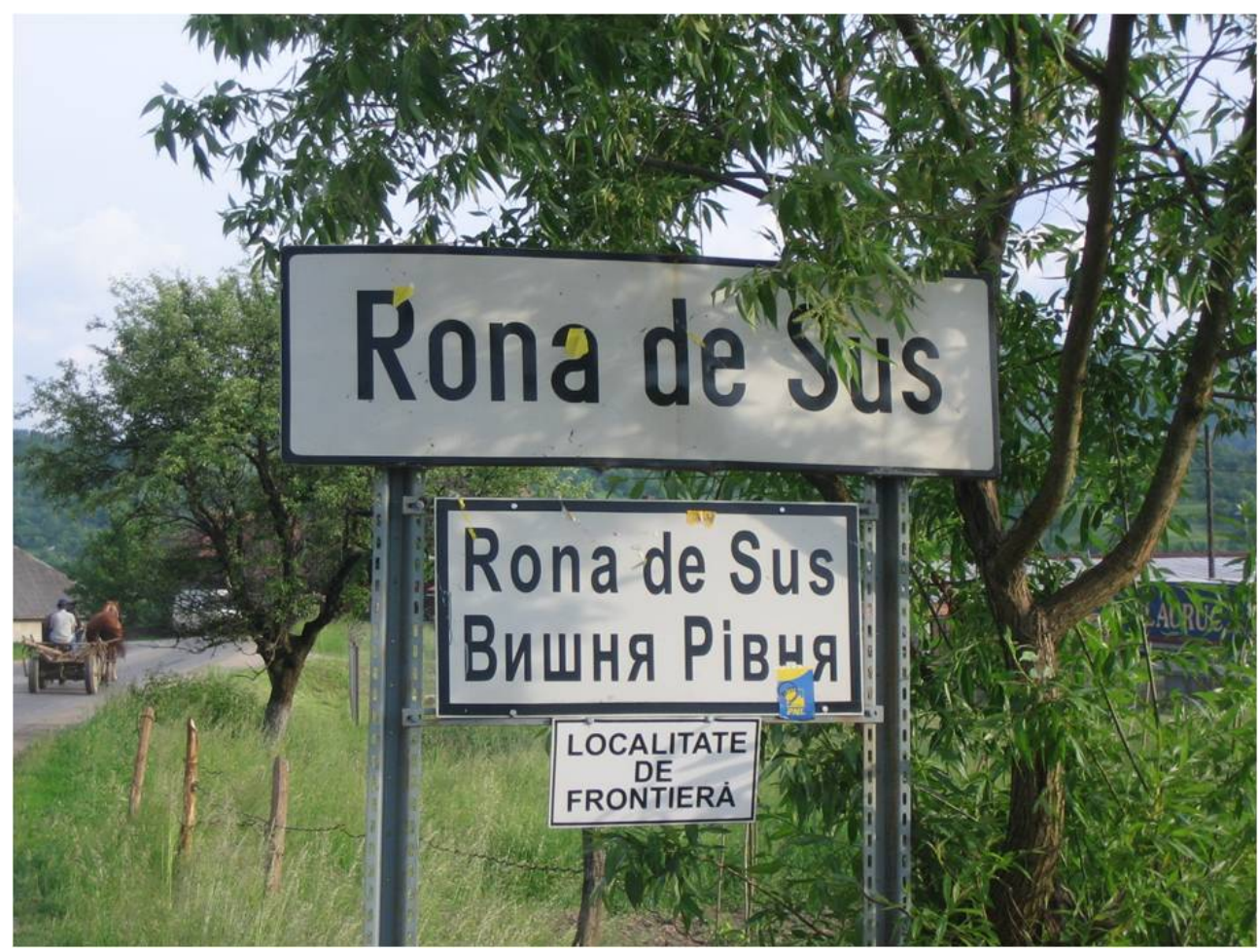

FIGURE 7: Signpost of a bilingual Romanian/Ukrainian village in the Romanian district [judeţ] Maramureş. The Ukrainian name is rendered in Cyrillic script (Photo May 2008).

REFERE N C E S

Boesch, E.E. 1983. Die Kulturbedingtheit des Menschen. In Paul Gordan (ed.), Mensch-Werden, Mensch-Sein, 339-369. Graz, Wien, Köln: Styria.

Christaller, W. 1933. Die zentralen Orte in Süddeutschland. Eine ökonomischgeographische Untersuchung über die Gesetz-

mäßigkeit der Verbreitung und Entwicklung der Siedlungen mit städtischen Funktionen. Jena: Fischer.

Jordan, P. 2009. Place names as ingredients of space-related identity. In Peter jordan, hubert bergmann, catherine cheetham, and isolde hausner (eds.), geographical names as a part of the cultural heritage, vol. 18, 33-39. Wien: Institut für Geographie und Regionalforschung der Universität Wien, Kartographie und Geoinformation. = Wiener Schriften zur Geographie und Kartographie. 
Kroeber, A.L \& C. Kluckhohn. 1963. Culture, a critical review of concepts and definitions. New York: Vintage Books.

Liouty, A.A. et al. (ed.). 1998. Resources and Environment. World Atlas. Moscow, Vienna: Ed. Hölzel.

Logar, T. \& J. Rigler. 2001. Slovene dialects. In Jerneja Fridl et al. (eds.), National Atlas of Slovenia, vol. 119. Ljubljana: Rokus.

Lévi-Strauss, C. 1949. Les structures élémentaires de la parenté. Paris.

Lévi-Strauss, C. 1966. Natur und Kultur. In Wilhelm E. Mühlmann (ed.), Kulturanthropologie, 80-107. Köln, Berlin: Kiepenheuer \& Witsch.

Mitchell, D. 2000. Cultural Geography. A Critical Introduction. Malden, Oxford, Carlton: Blackwell Publishing.

Sauer, C. 1925. The morphology of landscape. University of California Publications in Geography 2. 19-54.

Sauer, C. 1941. Foreword to historical geography. Annals of the Association of American Geographers 31. 1-24.

Tuan, Y. 1977. Space and place: The perspective of experience. Minneapolis: University of Minnesota Press.

Weichhart, P.,C. Weiske \& B. Werlen. 2006. Place identity und images: Das Beispiel Eisenhüttenstadt. Abhandlungen zur Geographie und Regionalforschung 9.

White, G. 2004. Nation, State, and Territory. Origins, Evolutions, and Relationships. Oxford: Rowman \& Littlefield Publishers.

AUTHOR CONTACT INFORMATION

Peter Jordan

Austrian Academy of Sciences

Institute of Urban and Regional Research

Postgasse $7 / 4 / 2$

A-1010 Wien

peter.jordan@oeaw.ac.at 